Lingua Rima: Jurnal Pendidikan Bahasa dan Sastra Indonesia

Vol. 11 No. 1 Januari 2022

http://jurnal.umt.ac.id/index.php/lgrm

\title{
EVALUASI PEMBELAJARAN DARING KRITIK SASTRA MELALUI LEARNING MANAGEMENT SYSTEM
}

\author{
Intan Sari Ramdhani \\ Universitas Muhammadiyah Tangerang \\ intan.sariramdhani@gmail.com
}

\begin{abstract}
ABSTRAK
Penelitian ini bertujuan untuk mendeskripsikan evaluasi pembelajaran daring pada mata kuliah kritik sastra melalui Learning Management System di Fakultas Keguruan dan Ilmu Pendidikan Program Studi Pendidikan Bahasa dan Sastra Indonesia di Universitas Muhammadiyah Tangerang. Metode penelitian yang digunakan dalam penelitian ini adalah metode deskriptif kualitatif dengan langkah-langkah mengumpulkan data, melakukan perekaman data, menganalisis data dan mendeskripsikan hasil penelitian. Objek penelitian ini adalah evaluasi pembelajaran daring melalui Learning Management System. Hasil penelitian menunjukkan bahwa 1) Pembelajaran Kritik Sastra yang dilakukan secara daring ini bermuara pada Learning Management System, 2) Learning Manjement System dapat menjadikan alternatif pembelajaran terbaik dalam situasi pandemi COVID-19, 3) Penggunaan LMS mudah dilaksanakan dalam pembelajaran Kritik Sastra, 4) Mahasiswa dapat mengahasilkan karya sendiri berupa buku antalogi kritik sastra, 5) Tujuan pembelajaran mata kuliah Kritik Sastra tercapai dengan penggunaan Learning Management System, 7) Merangsang sikap kritis dan kreatif mahasiswa untuk dapat mengkritik suatu karya sastra dalam pembelajaran Kritik Sastra, 8) Nilai pembelajaran Kritik Sastra menggunakan Learning Management ement System (LMS) menunjukkan nilai yang baik dan memuaskan, dan 9) Evaluasi pembelajaran yang dilihat melalui taksonomi bloom dapat tercapai dan respon mahasiswa terhadap pembelajaran daring mata kuliah Kritik Sastra menggunakan media pembelajaran Learning Management System (LMS) dikatakan baik.
\end{abstract}

Kata kunci: evaluasi pembelajaran, kritik sastra, LMS

\section{A. PENDAhuluan}

Kritik Sastra merupakan suatu bidang studi sastra untuk menghakimi karya sastra, untuk memberi penilaian dan keputusan mengenai bermutu atau tidaknya suatu karya sastra yang sedang dihadapi kritikus. Menurut Graham Hough (1996) kritik sastra itu bukan hanya terbatas pada penyuntingan dan penetapan teks, interpretasi , dan pertimbangan nilai, melainkan kritik sastra meliputi masalah yang lebih luas tentang apakah kesusastraan itu, untuk apa, dan bagaimana hubungannya dengan masalah-masalah kemanusiaan yang lain. Kritik sastra berasal dari kata 'kritikos' yang memiliki arti 'hakim kesusastraan'. Kritik 


\section{Lingua Rima: Jurnal Pendidikan Bahasa dan Sastra Indonesia \\ Vol. 11 No. 1 Januari 2022 \\ http://jurnal.umt.ac.id/index.php/lgrm}

sastra merupakan salah satu bentuk pembelajaran bahasa dan sastra Indonesia yang berada di perguruan tinggi. Mahasiswa Pendidikan Bahasa \& Sastra Indonesia di Universitas Muhammadiyah Tangerang tentunya mempelajari kritik sastra. Dengan mempelajari kritik sastra ini diharapkan mahasiswa mampu mengasah daya kritis keika dihadapkan suatu karya sastra dan dapat menangkap baik-buruk dan kurang-lebihnya suatu sastra, sehingga mahasiswa bisa berfikir ulang untuk bisa memunculkan opini baru.

Pembelajaran kritik sastra ini juga merupakan kegiatan yang kompleks. Karena mahasiswa dituntut untuk bisa mencari suatu karya sastra yang nantinya harus memberikan tanggapan terhadap hasil karya, memberikan pertimbangan baik dan buruk (kelebihan dan kekurangan) sebuah karya sastra, pertimbangan yang bersifat obyektif, memaparkan kesan pribadi kritikus terhadap sebuah karya sastra dan memberikan alternatif perbaikan atau penyempurnaan. Namun, karena pandemi, maka pembelajaran kritik sastra di UMT ini pun dilaksanakan secara daring dengan menggunakan Learning Management System (LMS). Learning management system (LMS) adalah perangkat lunak yang dirancang untuk membuat, mendistribusikan, dan mengatur penyampaian konten pembelajaran. Sistem ini bisa membantu para dosen khususnnya di Universitas Muhammadiyah Tangerang untuk merencanakan dan membuat silabus, mengelola bahan pembelajaran, mengelola aktivitas belajar para mahasiswa, mengelola nilai, memberikan tugas, UTS dan UAS. Karena berbasis aplikasi digital, selain memudahkan para dosen dalam merencanakan proses belajar online, LMS juga memudahkan mahasiswa untuk mengakses konten pembelajaran dari mana saja dan kapan saja. Dalam LMS itu sendiri sudah disiapkan berbagai fitur yang lengkap dimana mahasiswa dapat mengakses, diskusi forum, ujian, absensi, serta kuis. Kelebihan dari LMS ini sendiri mahasiswa akan terpantau langsung apabila tidak mengakses dan tidak ikut serta dalam pengumpulan tugas.

Evaluasi pembelajaran tetap diperlukan dalam pembelajaran jarak jauh seperti ini. Agar dosen dapat mengetahui dan melihat perkembangan mahasiswa dalam memahami kritik sastra. Evaluasi Pembelajaran adalah suatu proses menentukan tingkat pencapaian tujuan pembelajaran yang telah ditentukan sebelumnya melalui cara yang sistematis. Evaluasi pembelajaran bertujuan untuk mengumpulkan informasi yang menjadi landasan 


\section{Lingua Rima: Jurnal Pendidikan Bahasa dan Sastra Indonesia \\ Vol. 11 No. 1 Januari 2022 \\ http://jurnal.umt.ac.id/index.php/lgrm}

dalam mengukur tingkat kemajuan, perkembangan, dan pencapaian belajar peserta didik, serta keefektifan pendidik dalam mengajar. Pengukuran dan penilaian menjadi kegiatan utama dalam evaluasi pembelajaran. Evaluasi pembelajaran dapat dilihat dari aspek taksonomi bloom. Taksonomi berasal dari dua kata dalam bahasa Yunani yaitu tassein yang berarti mengklasifikasi dan nomos yang berarti aturan. Jadi Taksonomi berarti hierarkhi klasifikasi atas prinsip dasar atau aturan. Istilah ini kemudian digunakan oleh Benjamin Samuel Bloom, seorang psikolog bidang pendidikan yang melakukan penelitian dan pengembangan mengenai kemampuan berpikir dalam proses pembelajaran. Taksonomi bloom terdiri dari tiga ranah yaitu ranah kognitif, afektif dan psikomotorik.

Kaitan Learning Management System dengan kemandirian belajar adalah bahwa LMS ini adalah media pembelajaran e-learning yang didalamnya sudah disiapkan fitur-fitur lengkap untuk dieksplorasi mahasiswa sebagai pengganti pembelajaran tatap muka. Mahasiswa melakukan analisis, eksplorasi, penilaian, interpretasi, sintesis, dan informasi untuk memahami pembelajaran dan menghasilkan sebuah karya dari pembelajaran kritik sastra. Mahasiswa secara konstruktif melakukan pendalaman pembelajaran dengan memanfaatkan fitur-fitur di Learning Management system.

\section{B. METODELOGI PENELITIAN}

Penelitian ini dirancang dengan menggunakan metode penelitian deskriptif kualitatif. Penelitian ini dilakukan untuk mendeskripsikan penggunaan Learning Management System pada pembelajaran daring mata kuliah kritik sastra dan evaluasi yang didapat dari hasil belajar mahasiswa selama menggunakan LMS. Subjek penelitiannya adalah mahasiswa program studi Pendidikan Bahasa dan Sastra Indonesia semester 7 tahun ajaran 2020/2021, Fakultas Keguruan dan Ilmu Pendidikan Universitas Muhammadiyah Tangerang. Data penelitian ini adalah penggunaan Learning Management System (LMS). Peneliti menggunakan teknik observasi, kajian pustaka, dan dokumentasi untuk mengumpulkan data penelitian. Setelah mengumpulkan data, peneliti menganalisis data dengan cara mereduksi data, menyajikan data, dan menyimpulkan hasil penelitian.

\section{HASIL DAN PEMBAHASAN}




\section{Lingua Rima: Jurnal Pendidikan Bahasa dan Sastra Indonesia \\ Vol. 11 No. 1 Januari 2022 \\ http://jurnal.umt.ac.id/index.php/lgrm}

Berdasarkan hasil analisis data yang telah dilakukan, maka dapat diuraikan bahwa selama pandemic covid-19 pembelajaran mata kuliah kritik sastra di UMT dilaksanakan secara daring menggunakan media pembelajaran Learning Management System dan di akhir perkuliahan, mahasiswa diwajibkan untuk menulis kritik sastra yang kemudian di kumpulkan dalam buku antologi kritik sastra dari hasil pembelajaran kritik sastra. Penulisan karya kritik ini dilakukan secara individu. Dari setiap kelas akan menghasilkan 1 buah karya yaitu berupa buku antalogi kritik sastra. Learning Management System membantu memfasilitasi perkuliahan jarak jauh mata kuliah kritik sastra pada mahasiswa PBSI FKIP UMT. Hal tersebut dapat dilihat dari langkah-langkah pembelajaran dengan menggunakan LMS ini yaitu : pertama, pada langkah menyampaikan pertanyaan awal, dosen memotivasi mahasiswa dengan pengarahan dan materi-materi terkait pembelajaran kritik sastra di LMS. Kedua, pada langkah merencanakan tugas penulisan sebuah karya, mahasiswa dibimbing dosen untuk merencanakan sebuah karya berupa buku yang akan dilaksanakan atau menentukan aktivitas-aktivitas yang akan dikerjakan seperti menentukan karya sastra apa yang akan dijadikan bahan kritik sastra, menentukan pengarang, jenis karya sastra (puisi, prosa, atau drama), menentukan tema, memilih judul, melakukan interpretasi dan melakukan analisis kritik sastra terhadap suatu karya . Pada langkah kedua ini juga, dosen memberikan penjelasan tentang tugas penulisan suatu karya kritik melalui LMS dengan memberikan materi-materi kritik sastra yang dapat diunggah dan dipelajari oleh setiap mahasiswa dan memberikan kepercayaan serta tanggung jawab kepada mahasiswa untuk menyusun karya kritik menjadi sebuah antologi kritik sastra. Ketiga, pada langkah menjadwalkan tahap kegiatan pembuatan karya berupa buku berdasarkan perencanaan proyek, mahasiswa menyusun jadwal kegiatan atau aktivitas yang akan dikerjakan melalui penjadwalan dan urutan rencana perkuliahan semester (RPS) yang diunggah di LMS. Keempat, pada langkah pelaksanaan tugas penulisan karya kritik, dosen melakukan bimbingan kepada mahasiswa atau memonitoring sejauh mana proses penulisan kritik sastra dengan cara membuat forum diskusi di LMS.

Kelima, pada langkah penilaian tugas, dosen menilai hasil karya kritik yang dikumpulkan melalui LMS dan menyunting karya kritik mahasiswa kemudian memilih 10 


\section{Lingua Rima: Jurnal Pendidikan Bahasa dan Sastra Indonesia \\ Vol. 11 No. 1 Januari 2022 \\ http://jurnal.umt.ac.id/index.php/lgrm}

karya yang dijadikan antologi kritik per kelas.. Pada langkah penilaian ini, dosen menilai untuk mengukur ketercapaian tujuan pembelajaran menggunakan rubrik penilaian dalam buku hasil karya mahasiswa berupa antologi kritik sastra. Lalu, nilainya bisa langsung diketahui oleh mahasiswa melalui LMS. Keenam, pada langkah evaluasi tugas, dosen dan mahasiswa melakukan refleksi terhadap pembelajaran dan mahasiswa diberikan kesempatan untuk menyampaikan pengetahuan dan pengalaman baru yang didapatkan dari pembelajaran dan mengungkapkan perasaannya. Dari langkah-langkah di atas, maka dapat disimpulkan bahwa Learning Management System (LMS) mudah digunakan dan membantu proses pembelajaran daring kritik sastra.

Mahasiswa diberikan kepercayaan dan kebebasan dalam melaksanakan tugas penulisan sebuah karya kritik sastra dengan kemampuan berpikir kritis yang mereka miliki dan dari sumber inspirasi yang mereka peroleh secara individu sehingga mahasiswa menjadi lebih aktif, kreatif, kritis dan mandiri dalam menelaah dan mengkritik sebuah karya sastra untuk dijadikan sebuah antologi kritik sastra. Mahasiswa menjadi lebih aktif, karena mahasiswa secara intens melakukan pembimbingan dan konsisten selama proses penulisan kritik sebuah karya sastra . Mahasiswa menjadi lebih kritis, karena mahasiwa dapat menuangkan pikiran serta berpikir yang membangun (konstruktif) untuk mencari halhal yang dapat di kritik dari sebuah karya sastra itu sendiri. Mahasiswa menjadi lebih kreatif, karena mahasiswa mampu menuangkan gagasan dan mengeksplorasi potensi yang mereka miliki yang kemudian diwujudkan dalam bentuk karya berupa buku antologi kritik sastra. Bahkan kreativitas mahasiswa sangat terlihat di karya buku antologi kritik sastra yang mereka hasilkan, karena hampir 100\% mahasiswa menelaah dan mengkritik karya sastra.

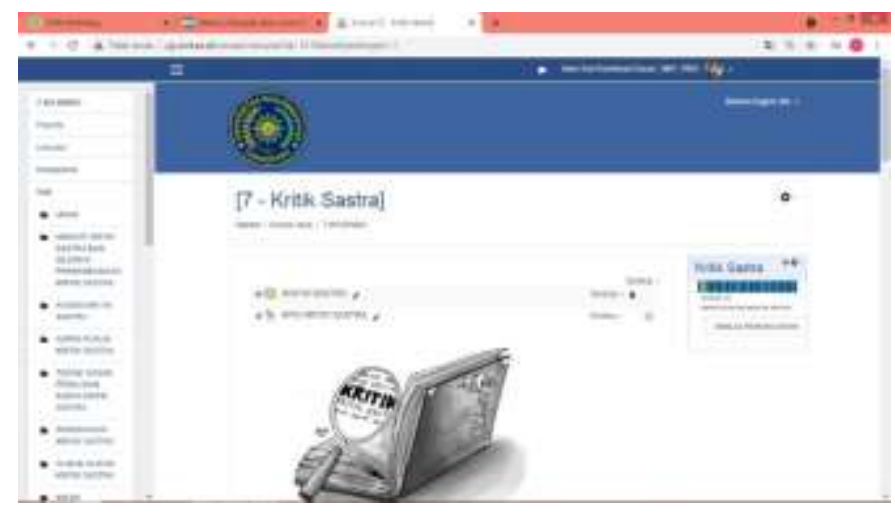




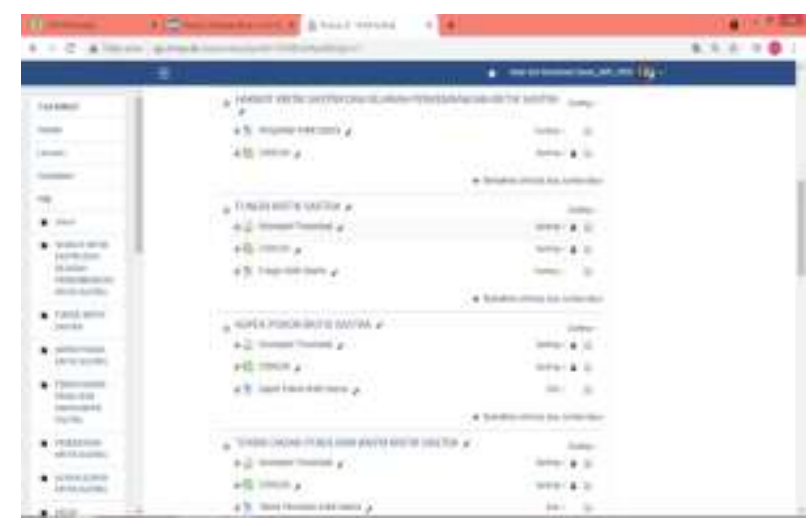

\section{Gambar 4.1 Learning Management System (LMS) Mata Kuliah Kritik Sastra}

Merujuk pada gambar 4.1 menampilkan fitur-fitur menarik di Learning Management System (LMS) mata kuliah kritik sastra yang didalamnya dapat diakses dengan mudah oleh mahasiswa. Mahasiswa dapat memahami, berdiskusi juga mengumpulkan tugas di forum yang sudah disediakan di LMS. Dan dari akhir perkuliahan mahasiswa diarahkan untuk membuat sebuah karya berupa buku antologi kritik sastra. Oleh karena itu, tujuan pembelajaran mata kuliah Kritik Sastra melalui Learning Management System (LMS) tercapai. Hal tersebut juga membuktikan bahwa pembelajaran kritik sastra menggunakan media pembelajaran LMS pada masa pandemic melalui daring ini tidak menurunkan semangat dan motivasi mahasiswa untuk belajar, melainkan mahasiswa tetap bisa produktif dalam hal penciptaan karya berupa buku antologi kritik sastra.
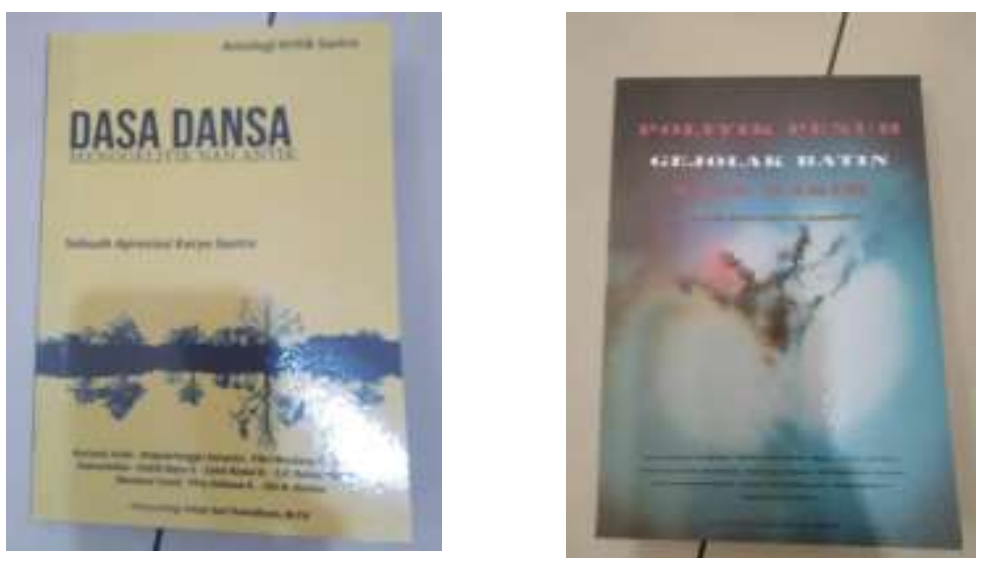

Gambar 4.2 Hasil Karya Buku Antologi Kritik Sastra Hasil Mahasiswa 
Merujuk pada gambar 4.2 yang merupakan hasil karya dari mata kuliah kritik sastra berupa buku antologi kritik sastra yang sudah ber ISBN. Buku antologi puisi ini berisi kumpulan kritik-kritik sastra dari beberapa karya sastra dari berbagai sastrawan . Kumpulan kritik sastra tersebut terdiri dari 10 kritik sastra terbaik yang dipilih oleh dosen yang dihasilkan oleh mahasiswa semester 7 kelas A1 dan A2. Dalam buku antologi kritik sastra tersebut mahasiswa dapat mengkritik sebuah karya sastra dengan baik dan menarik sesuai dengan pendekatan yang dipakai. Adapun judul-judul yag dipakai dalam analisis kritik sastra dari berbagai karya sastra sebagai berikut.

Tabel 4.1 Hasil Kritik Sastra Mahasiswa Semester 7 Kelas A1 Tahun Ajaran 2020/2021

\begin{tabular}{|c|c|c|}
\hline No. & Nama Mahasiswa & Judul Kritik sastra \\
\hline 1 & Nurlaely Aulia & $\begin{array}{c}\text { Menelaah Cerpen Perempuan itu Pernah Cantik } \\
\text { Karya Mashdar Zainal Melalui Perspektif Feminisme }\end{array}$ \\
\hline 2 & Dhipaerlangga Sanyoto & $\begin{array}{c}\text { Kritik Sastra Pada Cerpen Saksi Mata Karya Seno } \\
\text { Gumira Ajidarma Dengan Penddekatan Mimetik }\end{array}$ \\
\hline 3 & Fikri Maulana Syiba & Potret Pemudi Yogyakarta yang Eling Budaya \\
\hline 4 & Dithania Rahmahtika & $\begin{array}{c}\text { Kritik Objektif Terhadap Cerpen Cinta Yang } \\
\text { Sesungguhnya Karya Selda Arifani }\end{array}$ \\
\hline 5 & Habib Bayu Sampurno & $\begin{array}{c}\text { Kritik Sastra Merdeka Dalam Idealis Dengan } \\
\text { Pendekatan Pragmatik Pada Cerpen Si Tukang Kritik } \\
\text { Karya Andi D. Handoko }\end{array}$ \\
\hline 6 & Zaini Abdul Bahza & $\begin{array}{c}\text { Analisis Pendekatan Mimetik Dalam Cerpen Yang } \\
\text { Berjudul "Kematian Paman Gober" Karya Seno } \\
\text { Gumira Ajiharma }\end{array}$ \\
\hline 7 & Sri Purwanti Ratna N & $\begin{array}{c}\text { Kritik Ssatra Pada Cerpen Pendakian Dan Tamu Tak } \\
\text { Diundang Karya Rifky Hendrawan Dengan } \\
\text { Pendekatan Mimetik }\end{array}$ \\
\hline 9 & Maulana Yusuf & $\begin{array}{c}\text { Kritik Ekspresif Cerpen Jeda Karya hesty Nurul } \\
\text { Kusumaningtyas }\end{array}$ \\
\hline 10 & Firly Deliana Kholilah & $\begin{array}{c}\text { Tentang Dia Dan Mentari Yang Pergi Dalam Cerpen } \\
\text { Mentari Pergi Diujung Dermaga Ini Karya Kaka } \\
\text { Junie }\end{array}$ \\
\hline Siti Nur Annis & $\begin{array}{c}\text { Mengulik Kisa Si Perantau Yang Bernasib Baik } \\
\text { Dalam Cerpen Bingkisan Yang Tertukar Karya Silmi } \\
\text { Afkarina Hanum Cerpen dalam Koran Republika 26 } \\
\text { Juli 2020 }\end{array}$ \\
\hline
\end{tabular}


Lingua Rima: Jurnal Pendidikan Bahasa dan Sastra Indonesia

Vol. 11 No. 1 Januari 2022

http://jurnal.umt.ac.id/index.php/lgrm

Tabel 4.2 Hasil Kritik Sastra Mahasiswa Semester 7

Kelas A2 Tahun Ajaran 2020/2021

\begin{tabular}{|c|c|c|}
\hline No. & Nama Mahasiswa & Judul Kritik sastra \\
\hline 1 & Igasa Aditya Wardani & "Jasmine" Gadis Kecil Sang Ayah Dalam Sangkar \\
Kasih sayang
\end{tabular}

Berdasarkan tabel no 1 dan 2, hasil luaran mata kuliah kritik sastra ini menunjukan bahwa mahasiswa dapat dengan baik menulis sebuah kritik sastra dengan judul sangat menarik dan variatif. Karya kritik mahasiswa pun sesuai dengan hal hal yang harus diperhatikan dalam menganalisis kritik sastra dalam sebuah karya sastra. Dari berbagai judul tersebut, mahasiswa dapat dengan baik menulis dan menyusun karya kritik sastra. Menulis kritik sastra merupakan proses menganalisis, menginterpretasi dan "mengomentari" karya sastra yang dikritik. Sedangkan penyusunan merupakan proses menjadikan karya kritik sastra tersebut lebih menarik dibaca.

Evaluasi pembelajaran yang dihasilkan dari pembelajaran kritik sastra ini dapat dilihat dari aspek proses dan hasil belajar. Aspek proses dan hasil belajar merupakan hal yan penting dalam mengelola evaluasi pembelajaran dan menentukan tujuan pembelajaran tercapai atau tidak tercapai. Tujuan pembelajaran sering diklasifikasikan berdasarkan kategori tertentu seperti taksonomi Bloom atau taksonomi lainnya agar mudah diukur. Taksonomi adalah seperangkat prinsip-prinsip pengelompokan. Bloom membagi hasil belajar ke dalam ranah kognitif, afektif, dan psikomotorik. 


\section{Lingua Rima: Jurnal Pendidikan Bahasa dan Sastra Indonesia \\ Vol. 11 No. 1 Januari 2022 \\ http://jurnal.umt.ac.id/index.php/lgrm}

Ranah kognitif merupakan ranah yang berkaitan dengan pengetahuan . Kata kerja yang digunakan dalam jenjang ini adalah mengetahui, memahami makna, mengaplikasikan, menganalisis, mensintesis dan mengevaluasi. Kemampuan mengetahui merupakan jenjang yang paling rendah dalam ranah kognitif, yaitu kemampuan mengingat atau menghafal sesuatu yang pernah dipelajari sebelumnya baik berupa fakta, prinsip, teori, proses, pola dan struktur. Kemampuan memahami merupakan kemampuan siswa mempelajari bahanbahan yang dipelajari, memahami makna, menyatakan data dengan kata- kata sendiri, dan menerjemahkan. Kemampuan aplikasi merupakan kemampuan menggunakan teori-teori atau prinsip-prinsip, rumus-rumus atau abstraksi-abstraksi dalam situasi tertentu atau dalam situasi konkrit. Kemampuan menganalisis merupakan kemampuan siswa menafsirkan elemen-elemen, prinsip-prinsip pengorganisasian, struktur, konstruksi, hubungan internal, kualitas, dan reliabilitas komponen individual.

Kemampuan sintesis merupakan kemampuan menciptakan atau membangun. Kemampuan ini untuk keterampilan mengembangkan struktur, sistem, model, pendekatan, dan gagasan baru yang unik, berpikir kreatif dan pengoperasian. Kemampuan evaluasi merupakan kemampuan menilai efektivitas konsepsecara keseluruhan yang berkaitan dengan nilai-nilai, output, efektivitas, kelayakan, berpikir kritis, kaji ulang dan perbandingan stratejik, serta penilaian yang berkaitan dengan kriteria internal.Kemampuan ini dapat dites menggunakan soal pilihan ganda, mengingat fakta atau statistik, mengingat proses, aturan, definisi, dan mengutip hukum atau prosedur. Kemampuan ini dapat dites dengan menggunakan tugas-tugas yang disediakan di LMS. Dalam hal kognitif yang dapat dilihat dari pembelajaran kritik sastra melalui Learning Management System bahwa mahasiswa dapat dengan baik memahami materi, menganalisis dan mensintesis sebuah karya kritik sastra. Hal ini dapat dilihat dari tugas-tugas yang dikirimkan oleh mahasiswa di LMS dan din akhir perkuliahan telah terbukti bahwa mahasiswa dapat menghasilkan buah karya berupa buku antologi kritik sastra.

Ranah afektif terdiri dari lima tingkatan, yaitu menerima (receive), merespon, memberi nilai, mengorganisir atau mengonseptualisasi, dan menginternalisasi nilai. Tingkat menerima merupakan keterbukaan atas pengalaman, dan kemampuan mendengar. Tingkat 


\section{Lingua Rima: Jurnal Pendidikan Bahasa dan Sastra Indonesia \\ Vol. 11 No. 1 Januari 2022 \\ http://jurnal.umt.ac.id/index.php/lgrm}

merespon merupakan keterampilan mereaksi dan berpartisipasi secara aktif dalam kelompok diskusi, berpartisipasi secara aktif dalam sebuah kegiatan, tertarik akan hasil, antusias untuk bertindak, mempertanyakan dan memperdalam gagasan, dan menyarankan penafsiran. Tingkat menilai merupakan kemampuan melekatkan nilai dan mengemukakan pendapat pribadi. Tingkat menginternalisasi atau melakukan karakterisasi nilai merupakan kemampuan mengadopsi sistem dan filsafat. Dalam ranah afektif pembelajaran kritik sastra ini dapat berdampak pada sikap mahasiswa dalam pembelajaran kritik sastra. Meskipun pembelajaran dilakukan secara daring melalui LMS, mahasiswa dapat merespon dengan baik dan antusias juga berpartisipasi aktif dalam memahami dan mengerjakan tugas kritik sebuah karya sastra di LMS.

Ranah terakhir dalam taksonomi bloom yaitu ranah psikomotor yang berkaitan dengan keterampilan. Ranah psikomotor terdiri dari lima tingkat, yaitu imitasi, manipulasi, presisi, artikulasi dan naturalisasi. Kemampuan imitasi atau meniru merupakan kemampuan meniru tindakan orang lain, mengamati dan mereplikasi. Tingkat manipulasi merupakan kemampuan mereproduksi aktivitas berdasarkan instruksi atau dari ingatan. Tingkatan presisi atau keakuratan merupakan kemampuan mengeksekusi keterampilan secara andal, dan tanpa pertolongan orang lain. Tingkat artikulasi merupakan kemampuan mengadaptasi dan mengintegrasikan keahlian untuk memenuhi tujuan nonstandar. Tingkat naturalisasi merupakan kemampuan melakukan otomatisasi, dan penguasaan tindakan dan aktivitas secara tak disadari pada tingkat strategis. Dalam ranah psikomotor yang dapat dilihat dari pembelajaran kritik sastra ini yaitu mahasiswa dapat mengontruksi, memecahkan masalah, mengembangkan dan mennghasilkan sebuah karya kritik sastra berupa buku antologi kritik sastra.

Analisis taksonomi bloom terhadap pembelajaran kritik sastra melalui LMS, dapat disimpulkan bahwa Learning Management System (LMS) ini sangat berperan memfasilitasi perkuliahan jarak jauh dengan baik dan membantu memfasilitasi dosen untuk mengorganisasi materi pembelajaran dan nilai dalam sebuah sistem dan baik digunakan dalam pembelajaran daring mata kuliah Kritik Sastra. LMS ini juga memenuhi kriteria dalam evaluasi pembelajaran yang dilihat melalui taksonomi bloom. Pembelajaran berpusat 


\section{Lingua Rima: Jurnal Pendidikan Bahasa dan Sastra Indonesia \\ Vol. 11 No. 1 Januari 2022 \\ http://jurnal.umt.ac.id/index.php/lgrm}

pada siswa dan menerapkan kemampuan berpikir kritis untuk menghasilkan sebuah karya berupa buku antologi kritik sastra.

\section{SIMPULAN DAN SARAN}

Berdasarkan hasil dan pembahasan di atas, maka dapat disimpulkan bahwa evaluasi pembelajaran yang dilakukan melalui Learning Management System (LMS) dilihat dari taksonomi bloom berupa ranah kognitif, afektif dan psikomotorik cocok dan sangat baik digunakan dalam pembelajaran daring mata kuliah Kritik Sastra di perguruan tinggi karena dapat mengasah kemampuan berpikir kritis mahasiswa juga mengembangkan potensi yang mereka miliki serta mewujudkan kemandirian belajar di masa pandemic. Penggunaan LMS mampu memotivasi mahasiswa untuk tetap memahami pembelajaran kritik sastra, produktif, dalam hal ini menghasilkan sebuah karya berupa buku antologi kritik sastra. Penggunaan LMS dapat dilaksanakan dengan mudah dalam pembelajaran sehingga nilai mahasiswa pun baik dan memuaskan. Respon mahasiswa terhadap pembelajaran dari mata kuliah kritik sastra dengan melalui Learning Management System (LMS) ini menunjukan hasil yang baik dan ini juga membuktikan bahwa LMS dapat memberikan dampak yang baik bagi pembelajaran daring dan membawa pengaruh positif terhadap pembelajaran sehingga tujuan pembelajaran tercapai.

\section{E. DAFTAR PUSTAKA}

Ambarsari, Rika Yuni.2021. Evaluasi Pembelajaran Daring Selama Pandemi Covid-19 Di Kecamatan Bulukerto Wonogiri. Jurnal Ilmiah Mitra Swara Ganesha, ISSN 23563443 eISSN 2356-3451. Vol.8 No.1 (Januari 2021)

Andhi Anugrahana. 2020. Hambatan, Solusi dan Harapan: Pembelajaran Daring Selama Masa Pandemi Covid-19 Oleh Guru Sekolah Dasar. Jurnal Pendidikan dan Kebudayaan, Vol. 10 No. 3 : 282-289.

Cahyani, Okik Dwi. 2021. Evaluasi Pembelajaran Jarak Jauh Terhadap Hasil Belajar Mahasiswa Baru Pada Masa Pandemi Covid-19. Jurnal Pendidikan

Magdalena, Ina, dkk.2020. Konsep Dasar Evaluasi Pembelajaran Sekolah Dasar di SD Negeri Bencongan 1. : Jurnal Pendidikan dan Ilmu Sosial Volume 2, Nomor 1, April 2020; 87-98

Nuriyah, Nunung.2014. EVALUASI PEMBELAJARAN: Sebuah Kajian Teori. Jurnal Edueksos Vol III No 1, Januari-Juni 2014 


\section{Lingua Rima: Jurnal Pendidikan Bahasa dan Sastra Indonesia \\ Vol. 11 No. 1 Januari 2022 \\ http://jurnal.umt.ac.id/index.php/lgrm}

Idrus, L. 2019.Evaluasi Dalam Proses Pembelajaran. Volume. 9, No. 2 Agustus 2019 PISSN: 2407-8107 E-ISSN: 2685-4538

Satriawan, Sabar, dkk.2019. Studi Deskriptif Pembelajaran Tematik Dalam Membaca Dan Menulis Permulaan Dengan Menggunakan Metode Struktural Analitik Sentesis (SAS). JURNAL PEMBELAJARAN DAN PENGAJARAN PENDIDIKAN DASAR) Vol. 2 No. 2, 2019 P-ISSN : 2654-2870; E-ISSN 2686-5483

Yusuf, Abdul. 2021. Pengertian Kritik Sastra: Struktur, Manfaat dan Contoh. https://penerbitbuk udeepublish.com/pengertian-kritik-sastra/ (diakses 25 November 2021)

Viko.2014. Kritik \& Esai Sastra. http://vikochejr.blogspot.com/2014/02/kritik-esaisastra.html. (diakses tanggal 26 November 2021) 